Article

\title{
Development and Validation of a Method for the Analysis of Bisoprolol and Atenolol in Human Bone
}

\author{
Lucia Fernandez-Lopez ${ }^{1}$, Manuela Pellegrini ${ }^{2}$, Maria Concetta Rotolo ${ }^{2}$, Aurelio Luna ${ }^{1}$ (i), \\ Maria Falcon ${ }^{1, *}$ and Rosanna Mancini ${ }^{2}$ (D) \\ 1 Legal and Forensic Medicine, School of Medicine, University of Murcia,30100 Murcia, Spain \\ 2 National Centre on Drug Addiction and Doping, Istituto Superiore di Sanità, 00161 Rome, Italy \\ * Correspondence: falcon@um.es; Tel.: +34-868887583
}

Received: 28 May 2019; Accepted: 24 June 2019; Published: 29 June 2019

\begin{abstract}
A method based on gas chromatography-mass spectrometry (GC-MS) is described for the determination of bisoprolol and atenolol in human bone. After the addition of lobivolol as internal standard, pulverized samples were incubated in acetonitrile for $1 \mathrm{~h}$ under ultrasounds. After adjusting the $\mathrm{pH}$ of the samples to 6 , they were centrifuged, and the supernatants were subjected to solid phase extraction. Elution was achieved by using $3 \mathrm{~mL}$ of $2 \%$ ammonium hydroxide in 80:20 dichloromethane:isopropanol solution. Eluted samples were evaporated and derivatized. Chromatography was performed on a fused silica capillary column and analytes were determined in the selected-ion-monitoring (SIM) mode. The assay was validated in the range $0.1-0.3 \mathrm{ng} / \mathrm{mg}$ (depending on the drug) to $150 \mathrm{ng} / \mathrm{mg}$, the mean absolute recoveries were $60 \%$ for bisoprolol and $106 \%$ for atenolol, the matrix effect was $69 \%$ for bisoprolol and 70\% for atenolol and process efficiency was $41 \%$ for bisoprolol and $80 \%$ for atenolol. The intra- and inter-assay accuracy values were always better than $12 \%$. The validated method was then applied to bone samples from two real forensic cases in which toxicological analysis in blood were positive for atenolol in the first case $(0.65 \mu \mathrm{g} / \mathrm{mL})$ and bisoprolol in the second case $(0.06 \mu \mathrm{g} / \mathrm{mL})$. Atenolol was found in bone samples from the corresponding case at the approximate concentration of $148 \mathrm{ng} / \mathrm{mg}$ and bisoprolol was found at $8 \mathrm{ng} / \mathrm{mg}$.
\end{abstract}

Keywords: beta-blockers; human bone; gas chromatography-mass spectrometry

\section{Introduction}

In medico-legal death investigations, routine specimens typically collected at autopsies for toxicological analyses are blood, urine, gastric contents or vitreous humor. However, when long time has elapsed between death and sampling, these specimens are not available for the analysis due to the decomposition, so alternative matrixes are needed [1-3]. In case of significant putrefaction, skeletal tissues may provide the only source of information, since these specimens are well protected from decomposition [2-5]. In the last decade, skeletal tissues have been investigated as postmortem toxicological matrix by different authors who used a variety of methodologies for drugs extraction and detection [6-16]. Most researchers used experimental animals with the advantage of working under controlled conditions [2,4,6-21], while studies performed using human bones [1,5,22-29] are scarce and to date, do not use standardized protocols for sample preparation and analysis $[2,28,29]$.

Hypertension is a major public health issue, since it already affects one billion people worldwide, leading to heart attacks and strokes. Raised blood pressure currently kills nine million people every year, being responsible for at least $45 \%$ of deaths due to heart disease and $51 \%$ of deaths due to stroke [30,31]. With an increasing number of people suffering from hypertension every year, the use of cardiovascular drugs such as beta-blockers has increased as well [32]. Beta-blockers have been widely 
used in the treatment of hypertension for more than three decades [33] and are still recommended by international guidelines [34,35]. Since their mechanism of action consists of blocking beta-adrenergic receptors, they are also indicated in the management of heart failure, coronary artery disease or cardiac arrhythmia as well to reduce cardiovascular complications in the perioperative period [36-38]. Beta-blockers are also used for psychiatric disorders such as anxiety, aggressiveness or tremor [39], and due to improved psychomotor performance these drugs are also on the list of substances prohibited in several sport competitions by the World Anti-Doping Agency, such as archery, golf or automobile [40].

Atenolol is one of the beta-blockers most used, it was among the 200 most prescribed drugs in the United States in 2003, reaching the fourth place in 2005, with 44 million prescriptions yearly [32,41,42]. However, while the consumption of atenolol has been progressively decreasing over the years, the consumption of bisoprolol has been increasing, being currently bisoprolol the most used antihypertensive drug in Spain followed by atenolol [43]. In spite of their security, they were among the substances associated with largest number of fatalities in 2017 [44] and different case reports of deaths where a beta-blocker is suspected to be the cause have been published [45-49].

In previous research in our laboratory bisoprolol and atenolol were detected in post-mortem blood from real forensic cases, so in this paper, a simple and rapid gas chromatography-mass spectrometry (GC-MS) method for the simultaneous analysis of bisoprolol and atenolol in human bone samples was developed. The GC-MS method was validated and applied to the real forensic cases whose toxicological analyses for these drugs in blood were positive.

\section{Results}

\subsection{Gas Chromatography-Mass Spectrometry}

A chromatographic run was completed in $25 \mathrm{~min}$. No additional peaks due to endogenous substances that could interfere with the detection of the substances of interest were found in drug-free samples. Representative chromatograms obtained following the extraction of drug-free bone pool samples are shown in Figure 1A. Possible interferences between the substances were not found as is shown in the selected ion monitoring (SIM) chromatograms of an extract of $300 \mathrm{mg}$ of drug-free bone pool spiked with $50 \mathrm{ng}$ of bisoprolol and atenolol (Figure 1B). Carryovers were not found in blank samples injected after the highest point of the calibration curve.

\subsection{Validation Results}

Validation data are summarized in Tables 1 and 2. The determination coefficients $\left(\mathrm{r}^{2}\right)$ of linear calibration curves for the substances under study in bone samples were equal to or higher than 0.990 up to $150 \mathrm{ng} / \mathrm{mg}$ bone samples. The limit of detection (LOD) and limit of quantification (LOQ) of each analyte were satisfactory for the purpose of the study (Table 1). The inter- and intra-assay accuracy values obtained for the quality control (QC) samples were in all cases better than $12 \%$ (Table 2). The mean absolute recoveries were $60 \%$ for bisoprolol and $106 \%$ for atenolol, the matrix effect was $69 \%$ for bisoprolol and $70 \%$ for atenolol and process efficiency was $41 \%$ for bisoprolol and $80 \%$ for atenolol. The differences in concentration of QC samples after any of the three freeze/thaw cycles were lower than $10 \%$ compared with the initial concentration. Results obtained in mid-term stability test were similar, with differences below $10 \%$, ensuring the validity of the analysis of stored samples. 
A
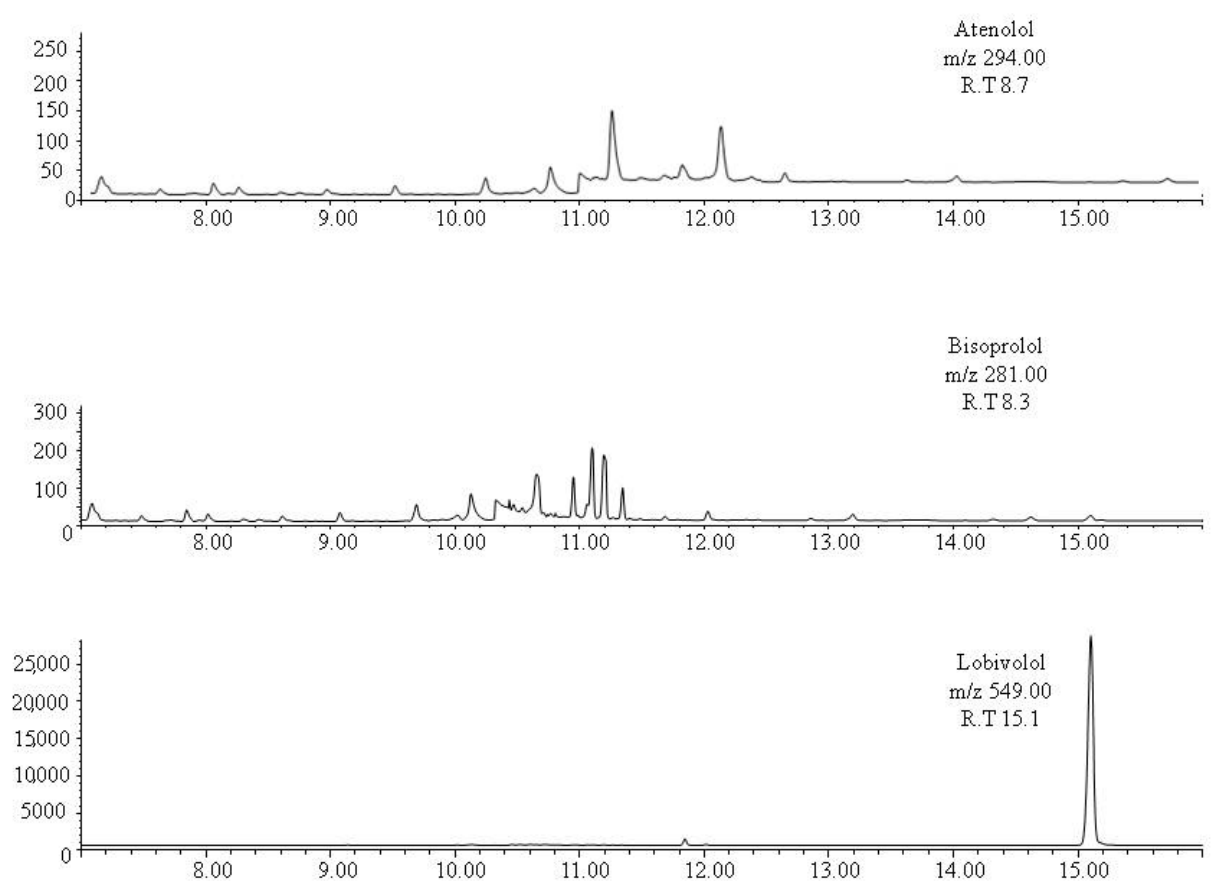

B
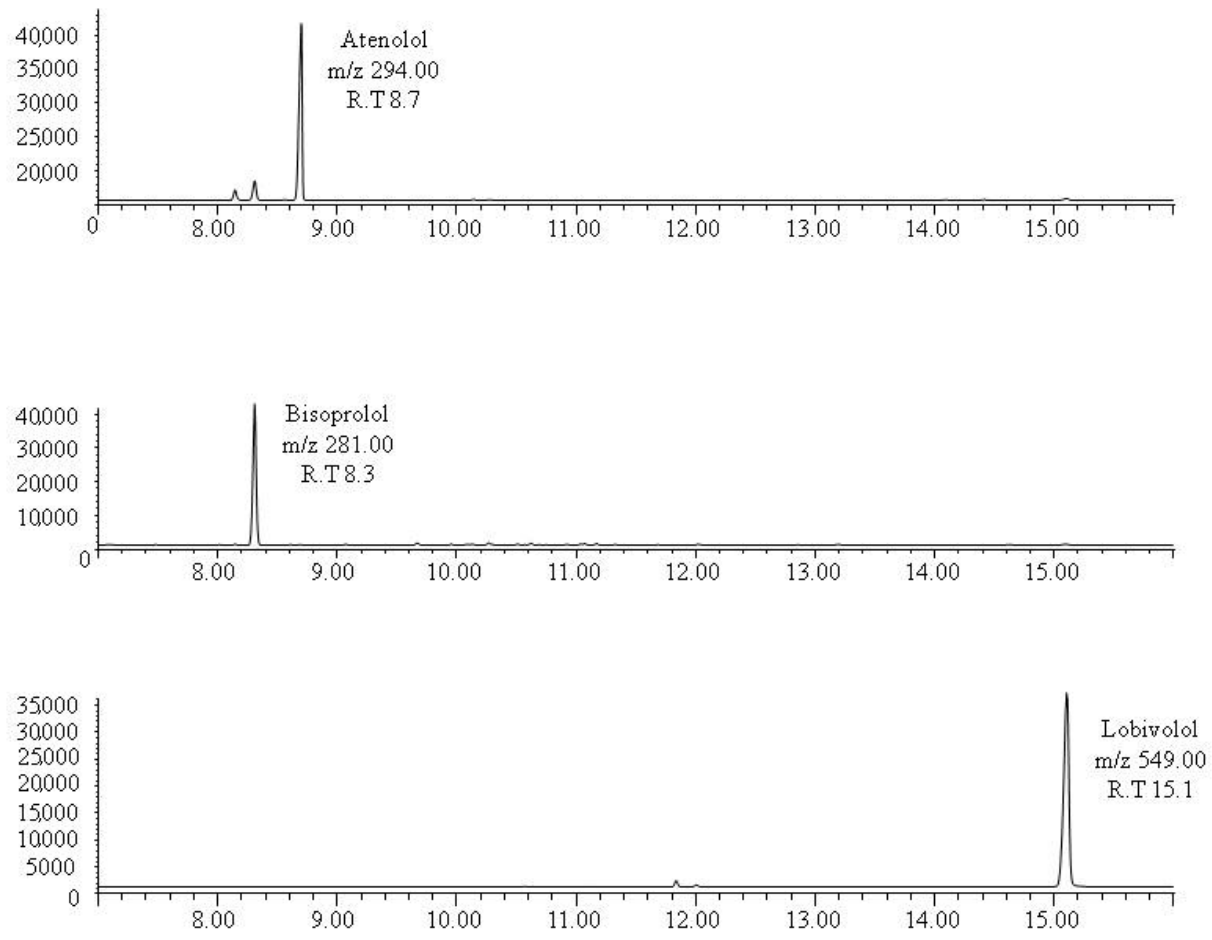

Figure 1. (A) Representative chromatograms obtained following the extraction of $300 \mathrm{mg}$ of drug-free bone pool spiked with the internal standard lobivolol. (B) Selected ion monitoring chromatogram of an extract of $300 \mathrm{mg}$ of drug-free bone pool spiked with $50 \mathrm{ng}$ of bisoprolol, atenolol and lobivolol. 
Table 1. Linearity results, limits of detection (LOD) and limits of quantification (LOQ values for analytes under investigation.

\begin{tabular}{ccccc}
\hline Analyte & \multicolumn{2}{c}{ Calibration Parameters } & LOD $^{\mathbf{b}}(\mathbf{n g} / \mathbf{m g})$ & LOQ $^{\mathbf{b}}(\mathbf{n g} / \mathbf{m g})$ \\
\hline Equation $^{\text {a }}$ & $\begin{array}{c}\text { Determination } \\
\text { Coefficients }\left(\mathbf{r}^{\mathbf{2}}\right)^{\mathbf{a}}\end{array}$ \\
\hline Atenolol & $\mathrm{Y}=0.0368 \mathrm{x}$ & 0.997 & 0.1 & 0.1 \\
Bisoprolol & $\mathrm{Y}=0.0168 \mathrm{x}$ & 0.999 & 0.3 & 0.0 \\
\hline \multicolumn{5}{c}{}
\end{tabular}

Table 2. Intra- and inter-assay $(n=3)$ precision and accuracy obtained for analytes under investigation.

\begin{tabular}{|c|c|c|c|c|c|c|c|c|c|c|c|}
\hline \multirow[t]{2}{*}{ Analyte } & \multicolumn{2}{|c|}{ Intra-Assay Precision (RSD) } & \multicolumn{3}{|c|}{$\begin{array}{l}\text { Intra-Assay Accuracy } \\
\text { (Absolute \%Error) }\end{array}$} & \multicolumn{3}{|c|}{$\begin{array}{l}\text { Inter-Assay Precision } \\
\text { (RSD) }\end{array}$} & \multicolumn{3}{|c|}{$\begin{array}{l}\text { Inter-Assay Accuracy } \\
\text { (Absolute \%Error) }\end{array}$} \\
\hline & $\mathrm{QCM}^{* *}$ & $\mathrm{QCH}^{* * *}$ & QCL & QCM & $\mathrm{QCH}$ & QCL & QCM & $\mathrm{QCH}$ & QCL & QCM & QCH \\
\hline Atenolol 5 & 5.4 & 2.1 & 7.09 & 0.95 & 1.36 & 5.3 & 5.7 & 2.1 & 11.89 & 6.90 & 2.03 \\
\hline Bisoprolol 2.5 & 1.6 & 1.7 & 9.39 & 6.06 & 1.66 & 1.5 & 0.3 & 2.2 & 0.94 & 2.71 & 0.16 \\
\hline
\end{tabular}

Relative standard deviation (RSD); * QCL: $20 \mathrm{ng} / \mathrm{mg}$; ${ }^{* *} \mathrm{QCM}: 40 \mathrm{ng} / \mathrm{mg} ;{ }^{* * *} \mathrm{QCH}: 130 \mathrm{ng} / \mathrm{mg}$.

\subsection{Application to Real Samples}

As the method showed satisfactory results in the validation protocol, it was applied to the analysis of real human bone samples taken from two corpses with positive blood toxicological tests for the drugs under study. The first case was positive to atenolol in blood at a concentration of $0.65 \mu \mathrm{g} / \mathrm{mL}$ which is within the therapeutic blood levels $(0.1-1 \mu \mathrm{g} / \mathrm{mL})$ and the second case was positive to bisoprolol with a blood concentration of $0.06 \mu \mathrm{g} / \mathrm{mL}$ which is also within the therapeutic blood levels $(0.01-$ $0.1 \mu \mathrm{g} / \mathrm{mL}$ ) [50]. Both drugs were detected in the corresponding bone sample. Atenolol was found in bone at the approximate concentration of $148 \mathrm{ng} / \mathrm{mg}$ and the level of bisoprolol was $8 \mathrm{ng} / \mathrm{mg}$. Representative chromatograms obtained following the extraction of real bone samples are shown in Figures 2 and 3.
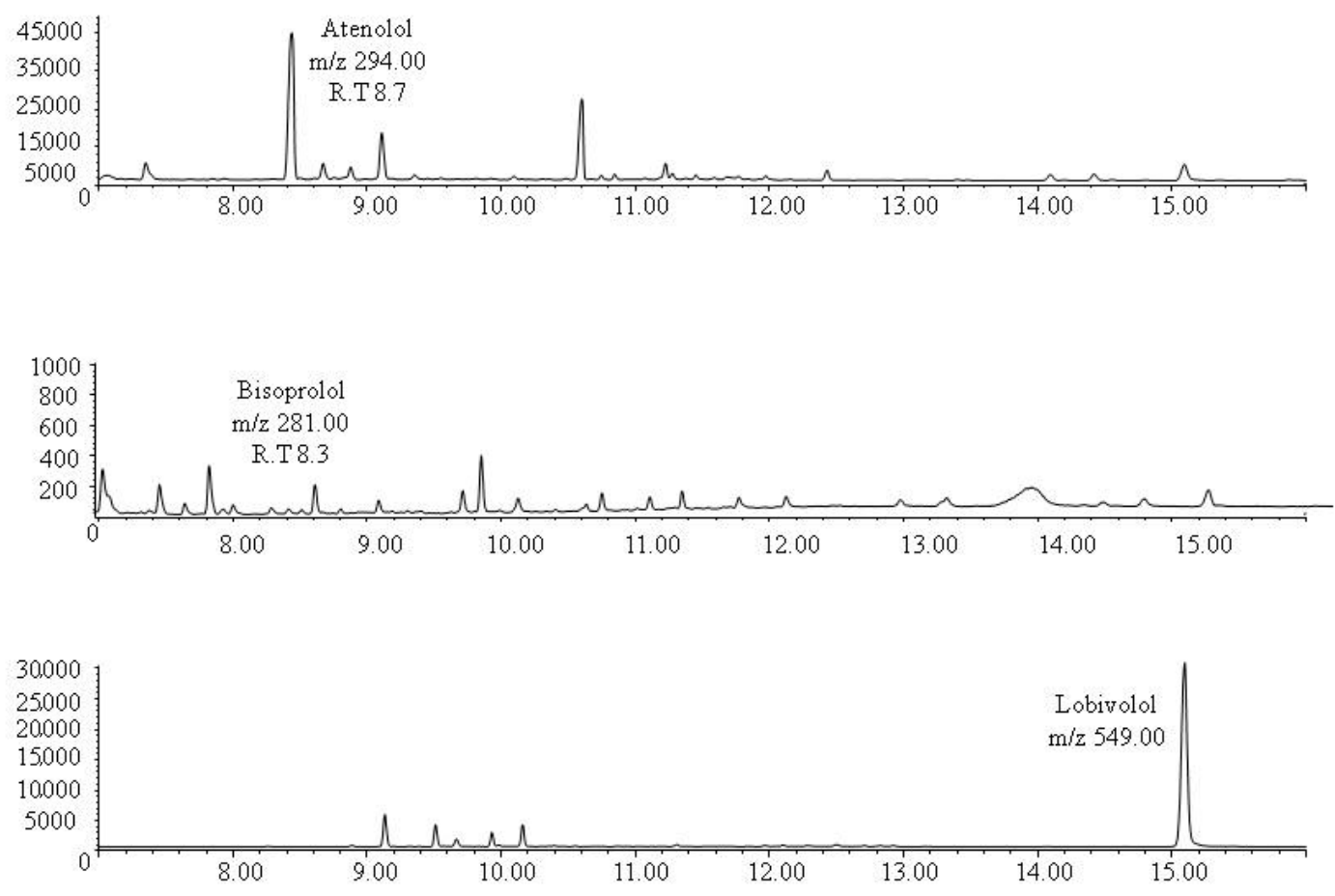

Figure 2. The SIM chromatogram of bones extracts from participant $n^{\circ} 1$ containing approximately $148 \mathrm{ng} / \mathrm{mg}$ bone atenolol. 

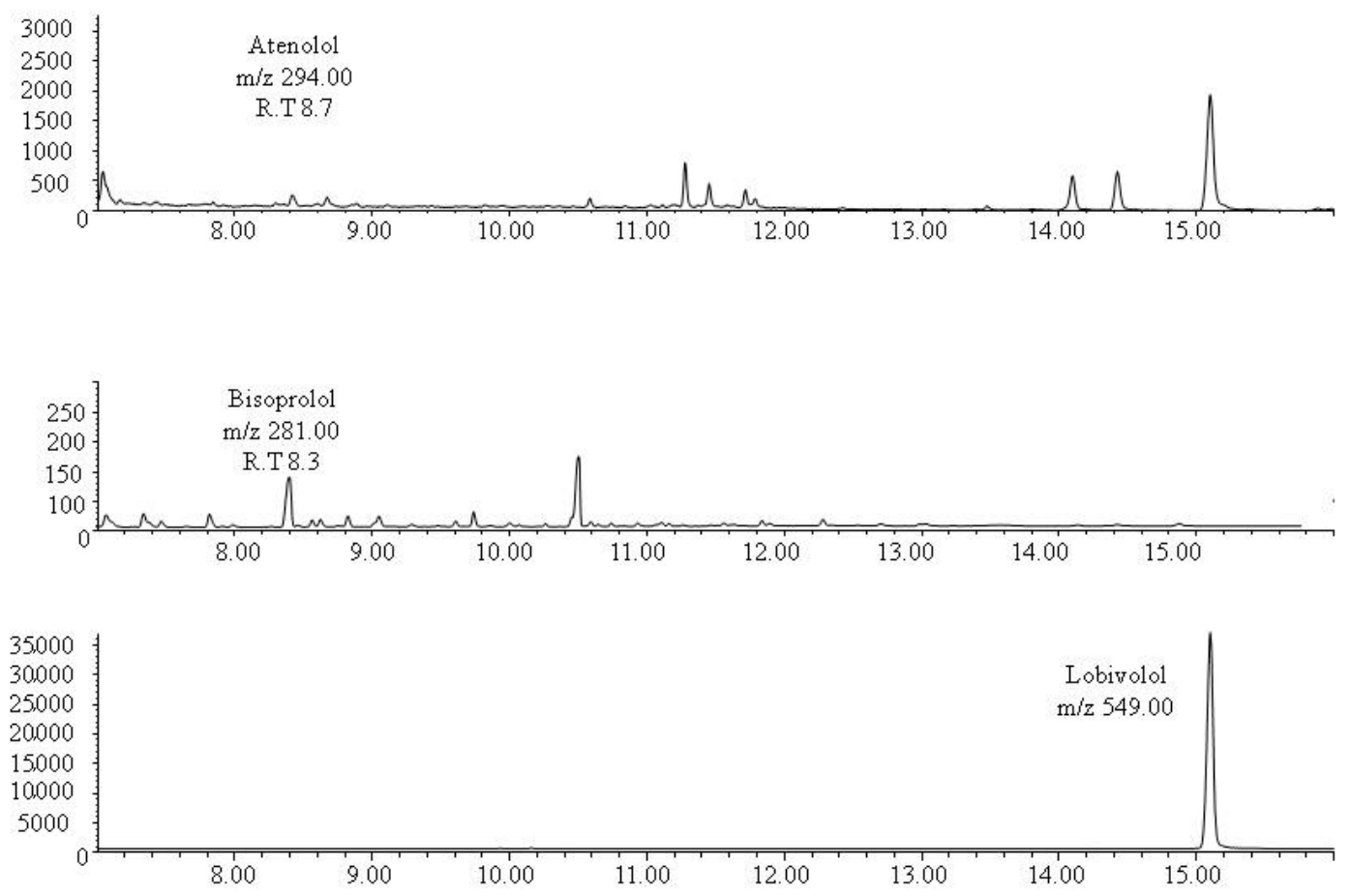

Figure 3. The SIM chromatogram of bones extracts from participant $\mathrm{n}^{\circ} 2$ containing approximately $8 \mathrm{ng} / \mathrm{mg}$ bone bisoprolol.

\section{Discussion}

Atenolol and bisoprolol had been previously studied in postmortem specimens such as blood, urine or hair $[32,40,48,51-54]$ but to our knowledge, they are analyzed in bone tissue here for the first time. At this time, these postmortem toxicological determinations in bone would inform about whether the deceased was exposed to the substance, but obtaining higher or lower levels would not report more information, since there is no standardized reference data of therapeutic and/or toxic bone concentrations of drugs in this matrix [50]. For this reason, the determination in future works of a correlation between drug concentrations in blood and bone would be very useful in these investigations, since it would give interpretative value to bone determinations.

In this work, both drugs were found in bone in a lower concentration than in blood, similarly to previous cases analyzed in our laboratory with other substances $[28,29]$. This may be due to the short time between death and sampling in these cases, since there would not have been enough time for substances from the decomposition fluids to deposit in bone tissue and so beta-blockers would have reached the bone mainly by its own vascularization. In this way, the level of drugs in bone would depend on the corresponding level in blood, which in turn depends on the drug administration route, the dose, the patterns of consumption (acute vs. chronic), the time between last exposure and death, etc. $[4,6,10,15-17]$. Another factor to consider would be the extent of metabolism of each beta-blockers. While the less lipophilic beta-blockers such as atenolol are excreted unchanged in higher rates, the more lipophilic substances are extensively metabolized to produce more water-soluble derivatives, making more likely to detect the metabolites than the mother drug [55]. As we can see, many factors would influence in drug levels in bone making postmortem toxicological investigation in this matrix very complex and even more if we consider that the majority of these parameters (administration route, dose, patterns of consumption, time between last exposure and death) are usually unknown in forensic cases.

Another consideration is the type of bone used for the analyses. The degree of vascularization of the bone depends on the anatomical site and the blood supply; moreover, trabecular bone is more vascularised than cortical bone due to the spongy structure [56]. Ribs are highly vascularised bones 
and contain considerable amount of bone marrow. A significant portion of the ribs is trabecular bone which allows a high contact surface of solid bone with bone marrow and blood and then with the eventual substances dissolved in them, making ribs a good option for toxicological investigations [29].

Cardiovascular drugs were among the substances most frequently involved in human poisonings in 2017 [44]. These poisoning have continuously increased since 2000, being beta-blockers among the substances associated with largest number of fatalities [44] and atenolol and bisoprolol among the beta-blockers most used. This work has demonstrated that atenolol and bisoprolol can be detected in bone tissue. This GC-MS method to analyse these beta-blockers in human bone was validated and tested in bone samples from forensic cases, evidencing the effectiveness of the method and the utility of human bone as toxicological matrix. However, further research is needed in this field increasing the number of patients and the beta-blockers analyzed.

\section{Materials and Methods}

\subsection{Chemicals and Reagents}

Bisoprolol, atenolol and lobivolol (internal standard) were supplied by the Reina Sofia University Hospital (Murcia, Spain). All the reagents were of analytical grade and were obtained from Carlo Erba (Milan, Italy).

\subsection{Bone Samples}

The bone samples were obtained from corpses autopsied in the Legal Medicine Institute of Murcia, Spain. The sample consisted of ten corpses showing negative blood toxicological results to the drugs under study and two more corpses showing positive blood toxicological results to the drugs of interest. The majority of the deceased were male (75\%); the average age was $55.9 \pm 7.8$ years (range $44-67$ years) and the average time from death to sampling was $20.1 \pm 7.8 \mathrm{~h}$ (range 2-32 h). Ethical approval was given by the Ethical Committee of the University of Murcia (ID: 1927/2018).

The bone samples consisted of fragments of approximately $5 \mathrm{~cm}$ in length taken from central part of the fifth or sixth true rib. Samples from corpses with negative blood toxicological results were postulated as possible drug-free samples and, after verification, bone samples were mixed to obtain a homogeneous pool of blank samples to be used for calibration standards and QC. Samples from corpses with positive blood toxicological results were included in the study in order to apply the method to real forensic cases.

\subsection{Preparation of Standard Solutions}

Stock standard solutions of bisoprolol and atenolol were prepared in methanol at $1 \mathrm{mg} / \mathrm{mL}$ and maintained at $-20{ }^{\circ} \mathrm{C}$ until analysis. Working solutions (100 and $\left.10 \mu \mathrm{g} / \mathrm{mL}\right)$ were prepared by dilution with methanol. The IS lobivolol was prepared at a $50 \mathrm{ng} / \mathrm{mL}$ concentration.

Calibration standards were prepared daily for each analytical batch by adding to $300 \mathrm{mg}$ of the pre-checked drug-free bone pool the suitable amounts of the methanol working solutions. The concentrations of the calibration standards were LOQ value, 10, 30, 50, 70 and $150 \mathrm{ng} / \mathrm{mg}$ bone. Three QC samples of each analyte were prepared at concentrations of $130 \mathrm{ng} / \mathrm{mg}$ (high quality control, QCH), $40 \mathrm{ng} / \mathrm{mg}$ (medium quality control, QCM) and $20 \mathrm{ng} / \mathrm{mg}$ (low quality control, QCL) in drug-free bone and stored at $-20{ }^{\circ} \mathrm{C}$.

\subsection{Sample Preparation}

Bone samples were conditioned as described in previous works [28,29]. Briefly, they were mechanically detached of remaining soft tissues and sectioned into small fragments, then they were dried at $50^{\circ} \mathrm{C}$ for $24 \mathrm{~h}$ and pulverized using a ball mill (Millmix 20, Biogen, Madrid, Spain). Three hundred milligrams of the resulting bone powder with the IS working solution and $1.5 \mathrm{~mL}$ of acetonitrile were vortexed and incubated for $1 \mathrm{~h}$ under ultrasounds. Then, $2 \mathrm{~mL}$ of phosphate buffered saline 
(PBS; $0.1 \mathrm{M}, \mathrm{pH}$ 6) were added; samples were centrifuged at $3500 \mathrm{~g}$ for $5 \mathrm{~min}$ and the supernatants were recovered.

\subsection{Solid-Phase Extraction}

Samples were then applied to CleanScreen PKG50 extraction columns (3 cc, $200 \mathrm{mg}$, United Chemical Technologies, Bristol, PA, USA) for a solid phase extraction (SPE). Cartridges were sequentially preconditioned with $2 \mathrm{~mL}$ of methanol followed by $2 \mathrm{~mL}$ of PBS. Samples were loaded onto the cartridges and allowed to flow by gravity and the columns were then washed sequentially with $2 \mathrm{~mL}$ of distilled water and $1 \mathrm{~mL}$ of $0.1 \mathrm{M}$ hydrochloric acid. Columns were dried under vacuum (10 in. $\mathrm{Hg}$ ) for approximately $5 \mathrm{~min}$ and washed again with $1 \mathrm{~mL}$ of methanol. Elution was achieved by using $3 \mathrm{~mL}$ of $2 \%$ ammonium hydroxide in 80:20 dichloromethane: isopropanol solution. Eluents were evaporated to dryness at $40{ }^{\circ} \mathrm{C}$ under a gentle stream of nitrogen and $100 \mu \mathrm{L}$ of $\mathrm{N}, \mathrm{O}$-bis(trimethylsilyl)trifluoroacetamide (BFTSA) $1 \%$ trimethylchlorosilane (TMCS) were added to dry extracts. Vials were then vortexed and derivatized for $30 \mathrm{~min}$ at $70{ }^{\circ} \mathrm{C}$ in capped test tubes. A $1-\mu \mathrm{L}$ aliquot was injected into the GC-MS system.

\subsection{Gas Chromatography-Mass Spectrometry Analysis}

Analysis was carried out using a 6890 Series Plus gas chromatograph equipped with an Agilent 7683 autosampler and coupled to a 5973N mass selective detector (Agilent Technologies, Palo Alto, CA, USA). Data were analysed using the standard software supplied by the manufacturer (Agilent Chemstation).

Analytes separation was performed on a fused silica capillary column (ZB-SemiVolatiles, $30 \mathrm{~m} \times$ $0.25 \mathrm{~mm}$ i.d., film thickness $0.25 \mu \mathrm{m}$, Phenomenex, Torrance, CA, USA). The oven temperature was programmed at $140{ }^{\circ} \mathrm{C}$ for $1 \mathrm{~min}$, increased to $230^{\circ} \mathrm{C}$ at $20^{\circ} \mathrm{C} / \mathrm{min}$ and held for $5 \mathrm{~min}$, then raised to $290^{\circ} \mathrm{C}$ at $20^{\circ} \mathrm{C} / \mathrm{min}$ and held for $20 \mathrm{~min}$. Splitless injection mode was used. Helium (purity $99 \%$ ), with a flow rate of $1 \mathrm{~mL} / \mathrm{min}$ was used as carrier gas.

The temperatures of the injection port, ion source, quadrupole and interface were: 260, 230, 150 and $280^{\circ} \mathrm{C}$, respectively. The electron-impact (EI) mass spectra of the compounds were recorded in total ion monitoring mode (scan range $40-550 \mathrm{~m} / \mathrm{z}$ ) to determine retention times and characteristic mass fragments. Then, the instrument was operated in SIM mode. The qualifying ions monitored in SIM mode appear in Table 3; the underlined ions were used for quantification. The ion ratio acceptance criterion was a deviation of $\leq 20 \%$ of the average of ion ratios of all the calibrators.

Table 3. Retention times and characteristic ions of analyzed substances by gas chromatography-mass spectrometry GC-MS.

\begin{tabular}{ccc}
\hline Substance & RT $(\mathbf{m i n})$ & Characteristic Mass Fragments $(\mathrm{m} / \mathrm{z})$ \\
\hline Atenolol & 8.7 & $72-223-294-395$ \\
Bisoprolol & 8.3 & $73-107-116-281$ \\
Lobivolol & 15.1 & $73-294-\underline{549-534}$ \\
\hline
\end{tabular}

RT: retention time. Underlined ions were used for quantification.

\subsection{Method Validation}

The method was subjected to a validation protocol following the international criteria most recently reported in forensic toxicology $[57,58]$. Selectivity, carryover, linearity, LOD and LOQ, precision, accuracy, matrix effect, recovery, process efficiency and stability were determined as in previous works $[28,29]$. Validation parameters were calculated using five different daily replicates of the three QC samples over three subsequent working days.

Selectivity was analysed by studying possible interferences due to endogenous substances and between the substances under study. Interferences due to endogenous compounds were assessed by measuring possible signals present at the retention times of the analytes under investigation and IS in 
the extracted pre-checked drug-free bone pool. By analysing the pre-checked drug-free bone pool with each compound added separately and all the compounds together, possible interferences between the substances were also determined.

Calibration curves were performed in triplicate for all the substances and peak area ratios between the analytes and the IS were calculated. The linearity was admitted as acceptable when the coefficient of determination was above 0.990 and the calibrators were quantified within $\pm 20 \%$ at the LOQ and $\pm 15 \%$ at other concentrations. Five replicates of blank samples were analysed and standard deviation (S.D.) of the mean noise level at the retention time window of each analyte was used for determining LOD $(\mathrm{LOD}=3$ S.D. $)$ and LOQ (LOQ $=10$ S.D.). To investigate possible carryovers at the analytes retention times under investigation, the extracted drug-free bone pool only spiked with the IS was injected into the GC-MS system just after the analysis of the highest concentration point of the calibration curve.

Precision and accuracy were analysed at the three QC concentrations and expressed as standard deviation and error (\%) of the measured values, respectively. They were expected to be less than $20 \%$. To determine the recovery, the matrix effects, and the process efficiency, the procedure proposed by Matuszewski et al. [59] was followed. In that protocol, three preparations were described: Set 1, Set 2 and Set 3. Set 1 was five replicates of QC material prepared in methanol and Sets 2 and 3 consisted of five replicates of the drug-free bone pool samples with QC material added after and before extraction, respectively. By comparing the mean peak area of analytes obtained in Set 3 (spiked before extraction) to those in Set 2 (spiked after extraction) recoveries were determined. By dividing the mean peak area of analytes obtained in Set 2 (spiked after extraction) to those in Set 1 (standard in methanol) matrix effects were calculated. And process efficiency was expressed as the ratio of the mean peak area of the analytes obtained in Set 3 (spiked before extraction) to those in Set 1 (standard in methanol).

The stability of the analytes in bone after freeze $\left(-20^{\circ} \mathrm{C}\right)$ thaw cycles was evaluated by analysing of three cycles on QC samples. Moreover, mid-term stability was tested for real samples stored at $-20^{\circ} \mathrm{C}$. Two samples were analysed in triplicate once a month over a period of six months. The stability was expressed as a percentage of the initial concentration (first analysed batch) of the analytes both in QC and real samples.

\subsection{Expression of Analyte Levels}

As described in previous studies using bone as toxicological matrix, the substance recovery from the bone tissue of corpses cannot be accurately determined due to the heterogeneity of the bone matrix, so drug levels in bone are reported as the response ratios (RR) normalized for the mass of tissue sampled $(\mathrm{RR} / \mathrm{m})[6-8]$. The $\mathrm{RR} / \mathrm{m}$ ratios are found proportional to the concentration in the validation protocol, so drugs levels can be compared with bone samples prepared in the same way over the range of concentrations assessed in the validation protocol. For better understanding, RR/m values have been expressed in concentration units (ng/mg), but they should only be used as approximations [7,12].

Author Contributions: Conceptualization, L.F.-L. and M.F.; methodology, R.M. and L.F.-L.; software, R.M. and M.C.R.; validation, R.M., M.C.R. and M.P.; formal analysis, M.C.R. and M.P.; investigation, L.F.-L. and M.F.; resources, A.L.; data curation, R.M. and M.P.; writing—original draft preparation, L.F.-L.; writing-review and editing, L.F.-L. and M.F.; visualization, A.L.; supervision, A.L.

Funding: This research received no external funding.

Conflicts of Interest: The authors declare no conflict of interest.

\section{References}

1. McGrath, K.K.; Jenkins, A.J. Detection of drugs of forensic importance in post-mortem bone. Am. J. Forensic Med. Pathol. 2009, 30, 40-44. [CrossRef] [PubMed]

2. Desrosiers, N.A.; Watterson, J.H.; Dean, D.E.; Wyman, J.F. Detection of amitriptyline and citalopram and metabolites in porcine bones following extended outdoor decomposition. J. Forensic Sci. 2012, 57, 544-549. [CrossRef] [PubMed] 
3. Watterson, J. Challenges in forensic toxicology of skeletonised human remains. Analyst 2006, 131, 961-965. [CrossRef] [PubMed]

4. Guillot, E.; de Mazancourt, P.; Durigon, M.; Alvarez, J.C. Morphine and 6-acetylmorphine concentrations in blood, brain, spinal cord, bone marrow and bone after lethal acute or chronic diacetylmorphine administration to mice. Forensic Sci. Int. 2007, 166, 139-144. [CrossRef]

5. Raikos, N.; Tsoukali, H.; Njau, S.N. Determination of opiates in postmortem bone and bone marrow. Forensic Sci. Int. 2009, 123, 140-141. [CrossRef]

6. Watterson, J.H.; Donohue, J.P.; Betit, C.C. Comparison of relative distribution of ketamine and norketamine in decomposed skeletal tissues following single and repeated exposures. J. Anal. Toxicol. 2012, 36, 429-433. [CrossRef]

7. Watterson, J.H.; Cornthwaite, H.M. Discrimination between patterns of drug exposure by toxicological analysis of decomposed skeletal tissues, Part II: Amitriptyline and Citalopram. J. Anal. Toxicol. 2013, 37, 565-572. [CrossRef]

8. Watterson, J.H.; Desrosiers, N.A.; Betit, C.C.; Dean, D.; Wyman, J.F. Relative distribution of drugs in decomposed skeletal tissues. J. Anal. Toxicol. 2010, 34, 510-515. [CrossRef]

9. Watterson, J.H.; Donohue, J.P. Relative distribution of ketamine and norketamine in skeletal tissues following various periods of decomposition. J. Anal. Toxicol. 2011, 35, 52-458. [CrossRef]

10. Watterson, J.H.; Desrosiers, N.A. Microwave-assisted extraction in the study of the effect of dose-death interval on meperidine detection in skeletal tissues. Forensic Sci. Int. 2011, 207, 40-45. [CrossRef]

11. Desrosiers, N.A.; Betit, C.C.; Watterson, J.H. Microwave-assisted extraction in toxicological screening of skeletal tissues. Forensic Sci. Int. 2009, 188, 23-30. [CrossRef] [PubMed]

12. Cornthwaite, H.M.; Labine, L.; Watterson, J.H. Semi-quantitative analysis of tramadol, dextromethorphan, and metabolites in decomposed skeletal tissues by ultra performance liquid chromatography quadrupole time of flight mass spectrometry. Drug Test. Anal. 2017, 10, 961-967. [CrossRef] [PubMed]

13. Gorczynski, L.Y.; Melbye, F.J. Detection of benzodiazepines in different tissues, including bone, using a quantitative ELISA assay. J. Forensic Sci. 2001, 46, 916-918. [CrossRef] [PubMed]

14. VandenBoer, T.C.; Grummett, S.A.; Watterson, J.H. Utility of immunoassay in drug screening in skeletal tissues: Sampling considerations in detection of ketamine exposure in femoral bone and bone marrow following acute administration using ELISA. J. Forensic Sci. 2008, 53, 1474-1482. [CrossRef] [PubMed]

15. Watterson, J.H.; VandenBoer, T.C. Effects of tissue type and the dose-death interval on the detection of acute ketamine exposure in bone marrow with solid-phase extraction and ELISA with liquid chromatography-tandem mass spectrometry confirmation. J. Anal. Toxicol. 2008, 32, 631-638. [CrossRef] [PubMed]

16. Watterson, J.H.; Botman, J.E. Detection of acute diazepam exposure in bone and marrow: Influence of tissue type and the dose-death interval on sensitivity of detection by ELISA with liquid chromatography tandem mass spectrometry confirmation. J. Forensic Sci. 2009, 54, 708-714. [CrossRef] [PubMed]

17. Lafreniere, N.M.; Watterson, J.H. Detection of acute fentanyl exposure in fresh and decomposed skeletal tissues. Part II: The effect of dose-death interval. Forensic Sci. Int. 2010, 94, 60-66. [CrossRef] [PubMed]

18. Cornthwaite, H.M.; Watterson, J.H. The influence of body position and microclimate on ketamine and metabolite distribution in decomposed skeletal remains. J. Anal. Toxicol. 2014, 38, 548-554. [CrossRef] [PubMed]

19. Unger, K.A.; Watterson, J.H. Analysis of dextromethorphan and dextrorphan in skeletal tissues following decomposition in different microclimates condition. J. Anal. Toxicol. 2016, 40, 669-676. [CrossRef]

20. Lafreniere, N.M.; Watterson, J.H. Detection of acute fentanyl exposure in fresh and decomposed skeletal tissues. Forensic Sci. Int. 2009, 185, 100-106. [CrossRef]

21. Ceigniz, S.; Ulukan, O.; Ates, I.; Tugcu, H. Determination of morphine in postmortem rabbit bone marrow and comparison with blood morphine concentrations. Forensic Sci. Int. 2006, 156, 91-94.

22. Horak, E.L.; Jenkins, A.J. Postmortem tissue distribution of olanzapine and citalopram in a drug intoxication. J. Forensic Sci. 2005, 50, 1-3. [CrossRef]

23. McIntyre, I.M.; King, C.V.; Boratto, M.; Drummer, O.H. Postmortem drug analyses in bone and bone marrow. Ther. Drug Monit. 2000, 22, 79-83. [CrossRef] [PubMed] 
24. Orfanidis, A.; Gika, H.; Mastrogianni, O.; Krokos, A.; Theodoridis, G.; Zaggelidou, E.; Raikos, N. Determination of drugs of abuse and pharmaceuticals in skeletal tissue by UHPLC-MS/MS. Forensic Sci. Int. 2018, 290, 137-145. [CrossRef] [PubMed]

25. Vardakou, I.; Athanaselis, S.; Pistos, C.; Papadodima, S.; Spiliopoulou, C.; Moraitis, K. The clavicle bone as an alternative matrix in forensic toxicological analysis. J. Forensic Leg. Med. 2014, 22, 7-9. [CrossRef] [PubMed]

26. Kudo, K.; Sugie, H.; Syoui, N.; Kurihara, K.; Jitsufuchi, N.; Imamura, T.; Ikeda, N. Detection of triazolam in skeletal remains buried for 4 years. Int. J. Leg. Med. 1997, 110, 281-283. [CrossRef]

27. Orfanidis, A.; Gika, H.; Zaggelidou, E.; Mastrogianni, O.; Raikos, N. Alprazolam and Zolpidem in Skeletal Tissue of Decomposed Body Confirms Exposure. J. Forensic Sci. 2019, 64, 643-646. [CrossRef] [PubMed]

28. Fernandez-Lopez, L.; Luna-Maldonado, A.; Falcon, M.; Mastrobattista, L.; Navarro-Zaragoza, J.; Mancini, R. Development and validation of a gas chromatography-mass spectrometry method for opiates and cocaine in human bone. J. Pharm. Biomed. Anal. 2019, 164, 636-641. [CrossRef]

29. Fernandez-Lopez, L.; Pellegrini, M.; Rotolo, M.C.; Luna, A.; Falcon, M.; Mancini, R. Development and validation of a method for analysing of duloxetine, venlafaxine and amitriptyline in human bone. Forensic Sci. Int. 2019, 299, 154-160. [CrossRef]

30. World Health Organization. The Global Burden of Disease: 2004 Update. Geneva (2008). Available online: https://www.who.int/healthinfo/global_burden_disease/2004_report_update/en/ (accessed on 2 May 2019).

31. Lim, S.S.; Vos, T.; Flaxman, A.D.; Danaei, G.; Shibuya, K.; Adair-Rohani, H.; A AlMazroa, M.; Amann, M.; Anderson, H.R.; Andrews, K.G.; et al. A comparative risk assessment of burden of disease and injury attributable to 67 risk factors and risk factor clusters in 21 regions, 1990-2010: A systematic analysis for the Global Burden of Disease Study 2010. Lancet 2012, 380, 2224-2260. [CrossRef]

32. Johnson, R.D.; Russell, J.L. Quantitation of atenolol, metoprolol, and propranolol in postmortem human fluid and tissue specimens via LC/APCI-MS. Forensic Sci. Int. 2006, 156, 106-117. [CrossRef] [PubMed]

33. Bangalore, S.; Messerli, F.H.; Kostis, J.B.; Pepine, C.J. Cardiovascular protection using beta-blockers: A critical review of the evidence. J. Am. Coll. Cardiol. 2007, 50, 563-572. [CrossRef] [PubMed]

34. Grassi, G. The European Society of Cardiology (ESC)/European Society of Hypertension (ESH) 2018 guidelines for hypertension diagnosis and treatment: New concepts and recommendations. Pharmacol. Res. 2019, 139, 489-490. [CrossRef] [PubMed]

35. Chobanian, A.V.; Bakris, G.L.; Black, H.R.; Cushman, W.C.; Green, L.A.; Izzo, J.J.L.; Jones, D.W.; Materson, B.J.; Oparil, S.; Wright, J.J.T.; et al. The seventh report of the Joint National Committee on Prevention, Detection, Evaluation, and Treatment of High Blood Pressure: The JNC 7 report. JAMA 2003, 289, 2560-2572. [CrossRef] [PubMed]

36. Freemantle, N.; Cleland, J.; Young, P.; Mason, J.; Harrison, J. Beta Blockade after myocardial infarction: Systematic review and meta regression analysis. BMJ 1999, 318, 1730-1737. [CrossRef] [PubMed]

37. Brophy, J.M.; Joseph, L.; Rouleau, J.L. Beta-blockers in congestive heart failure. A Bayesian meta-analysis. Ann. Intern. Med. 2001, 134, 550-560. [CrossRef] [PubMed]

38. Mangano, D.T.; Layug, E.L.; Wallace, A.; Tateo, I. Atenolol reduced mortality and cardiovascular events after noncardiac surgery. N. Engl. J. Med. 1996, 335, 1713-1720. [CrossRef] [PubMed]

39. Newman, W.J.; Xiong, G.L.; Barnhorst, A.V. Beta-Blockers: Off-Label Use in Psychiatric Disorders. Psychopharm Rev. 2013, 48, 73-80. [CrossRef]

40. World Anti-Doping Agency. Prohibited List. The World Anti-Doping Code International Standard. 2019. Available online: https://www.wada-ama.org/ (accessed on 2 May 2019).

41. Wiysonge, C.S.; Bradley, H.A.; Volmink, J.; Mayosi, B.M.; Opie, L.H. Beta-blockers for hypertension. Cochrane Database Syst. Rev. 2017, 1. [CrossRef] [PubMed]

42. Berenson, A. Big drug makers see sales decline with their image. The New York Times, 14 November 2005.

43. Agencia Española de Medicamentos y Productos Sanitarios. Observatorio de uso d Medicamentos. Utilización de Medicamentos Antihipertensivos en España Durante el Periodo 2010-2017. Available online: https://www.aemps.gob.es/en/medicamentosUsoHumano/observatorio/ informes-publicados/informes-antihipertensivos-espana-2010-2017.htm (accessed on 2 May 2019).

44. Gummin, D.D.; Mowry, J.B.; Spyker, D.A.; Brooks, D.E.; Osterthaler, K.M.; Banner, W. 2017 Annual Report of the American Association of Poison Control Centers' National Poison Data System (NPDS): 35th Annual Report. Clin. Toxicol. 2018, 56, 1213-1415. [CrossRef] [PubMed] 
45. Mozayani, A.; Singer, P.; Jones, G. Distribution of metoprolol enantiomers in a fatal overdose. J. Anal. Toxicol. 1995, 19, 519-521. [CrossRef] [PubMed]

46. Kinoshita, H.; Taniguchi, T.; Nishiguchi, M.; Ouchi, H.; Minami, T.; Utsumi, T.; Motomura, H.; Tsuda, T.; Ohta, T.; Aoki, S.; et al. An autopsy case of combined drug intoxication involving verapamil, metoprolol and digoxin. Forensic Sci. Int. 2003, 133, 107-112. [CrossRef]

47. Fucci, N.; Offidani, C. An unusual death by propranolol ingestion. Am. J. Forensic Med. Pathol. 2000, 21, 56-58. [CrossRef] [PubMed]

48. Weinstein, R.S.; Cole, S.; Knaster, H.B.; Dahlbert, T. Beta blocker overdose with propranolol and with atenolol. Ann. Emerg. Med. 1985, 14, 161-163. [CrossRef]

49. Buajordet, I.; Ebbesen, J.; Erikssen, J.; Brørs, O.; Hilberg, T. Fatal adverse drug events: The paradox of drug treatment. J. Intern. Med. 2001, 250, 327-341. [CrossRef] [PubMed]

50. Schulz, M.; Schmoldt, A. Therapeutic and toxic blood concentrations of more than 800 drugs and other xenobiotics. Pharmazie 2003, 58, 447-474. [PubMed]

51. Canfield, D.V.; Dubowski, K.M.; Whinnery, J.M.; Forster, E.M. Pilot-reported beta-blockers identified by forensic toxicology analysis of postmortem specimens. J. Anal. Toxicol. 2017, 42,1-5. [CrossRef]

52. Krumbiegel, F.; Hastedt, M.; Tsokos, M. Nails are a potential alternative matrix to hair for drug analysis in general unknown screenings by liquid-chromatography quadrupole time-of-flight mass spectrometry. Forensic Sci. Med. Pathol. 2014, 10, 496-503. [CrossRef]

53. Launiainen, T.; Ojanperä, I. Drug concentrations in post-mortem femoral blood compared with therapeutic concentrations in plasma. Drug Test. Anal. 2014, 6, 308-316. [CrossRef]

54. Kristoffersen, L.; Øiestad, E.L.; Opdal, M.S.; Krogh, M.; Lundanes, E.; Christophersen, A.S. Simultaneous determination of 6 beta-blockers, 3 calcium-channel antagonists, 4 angiotensin-II antagonists and 1 antiarrhytmic drug in post-mortem whole blood by automated solid phase extraction and liquid chromatography mass spectrometry: Method development and robustness testing by experimental design. J. Chromatogr. B Anal. Technol. Biomed. Life Sci. 2007, 850, 147-160.

55. Jankovic, S.M. Pharmacokinetics of selective $\beta 1$-adrenergic blocking agents: Prescribing implications. Expert Opin. Drug Metab. Toxicol. 2014, 10, 1221-1229. [CrossRef] [PubMed]

56. Clarke, B. Normal bone anatomy and physiology. Clin. J. Am. Soc. Nephrol. 2008, 3, S131-S139. [CrossRef] [PubMed]

57. Wille, S.M.R.; Coucke, W.; De Baere, T.; Peters, F.T. Update of Standard Practices for New Method Validation in Forensic Toxicology. Curr. Pharm. Des. 2017, 23, 5442-5454. [CrossRef] [PubMed]

58. Peters, F.T.; Wissenbach, D.K.; Busardò, F.P.; Marchei, E.; Pichini, S. Method Development in Forensic Toxicology. Curr. Pharm. Des. 2017, 23, 5455-5467. [CrossRef] [PubMed]

59. Matuszewski, B.K.; Constanzer, M.L.; Chavez-Eng, C.M. Strategies for the assessment of matrix effect in quantitative bioanalytical methods based on HPLC-MS/MS. Anal. Chem. 2003, 75, 3019-3030. [CrossRef] [PubMed]

(C) 2019 by the authors. Licensee MDPI, Basel, Switzerland. This article is an open access article distributed under the terms and conditions of the Creative Commons Attribution (CC BY) license (http://creativecommons.org/licenses/by/4.0/). 